\title{
PERKEMBANGAN PENDAPATAN MUSTAHIK ZAKAT PRODUKTIF BAZNAS KABUPATEN TANAH DATAR (Studi terhadap Mustahik Usaha Dagang Di Kecamatan Lima Kaum)
}

\author{
Widi Nopiardo \\ Institut Agama Islam Negeri Batu Sangkar \\ E-mail: widinopiardo@iainbatusangkar.ac.id
}

\begin{abstract}
Abstrak,
Permasalahan dalam penelitian ini adalah bagaimana perkembangan pendapatan mustahik zakat produktif BAZNAS KabupatenTanah Datar khususnya yang menjalankan usaha dagang di Kecamatan Lima Kaum. Jenis penelitian yang penulis lakukan adalah field research yaitu penelitian lapangan yang bersifat deskriptif kualitatif. Teknik pengumpulan data melalui observasi, wawancara, dan dokumentasi. Data ditelaah dan dianalisis dengan berbagai landasan teori untuk menarik kesimpulan. Berdasarkan hasil penelitian yang dilakukan pada BAZNAS Kabupaten Tanah Datarmaka dapat disimpulkan bahwa sebelum pendistribusian dana zakat oleh BAZNAS Kabupaten Tanah Datar pendapatan mustahik tidak dapat mencukupi kebutuhan mustahik sehari-hari, tetapi setelah menerima bantuan zakat produktif, pendapatan mustahik rata-rata meningkat sebesar $57 \%$ dari pendapatan sebelum menerima zakat. Hal ini membuktikan bahwa pendistribusian dana zakat produktif sangat mempengaruhi perkembangan pendapatan mustahik yang ada di Kecamatan Lima Kaum.
\end{abstract}

Kata Kunci: Pendapatan Mustahik, Zakat Produktif, BAZNAS Kabupaten Tanah Datar

\begin{abstract}
,
The problem in this study is how the development of productive income of BAZNAS Mustahik in Tanah Datar Regency, especially those who run a business in the District of Lima Kaum. The type of research that the authors do is field research, namely field research that is descriptive qualitative. Data collection techniques through observation, interviews, and documentation. Data is analyzed and analyzed with various theoretical foundations to draw conclusions. Based on the results of research conducted in BAZNAS Tanah Datarmaka Regency, it can be concluded that before the distribution of zakat funds by BAZNAS, Tanah Datar Regency, mustahik income cannot meet the needs of daily mustahik, but after receiving productive zakat assistance, average mustahik income increased by $57 \%$ of revenue before receiving zakat. This proves that the distribution of productive zakat funds greatly influences the development of mustahik income in Lima Kaum District.
\end{abstract}

Keyword : Mustahik's Income, Productive Zakat, BAZNAS Tanah Datar Regency

\section{PENDAHULUAN}

Islam adalah agama yang sempurna diturunkan oleh Allah Swt ke muka bumi untuk menjadi rahmatan lialamin (rahmat bagi seluruh alam). Islam adalah satu-satunya agama Allah yang memberikan panduan yang lugas dan dinamis terhadap aspek kehidupan manusia kapan saja dan dalam berbagai situasi, di samping itu mampu menghadapi dan 
menjawab berbagai macam tantangan pada setiap zaman. Islam mengatur tatanan hidup dengan sempurna, tidak hanya mengatur masalah ibadah seseorang pada Tuhannya, tetapi juga mengatur masalah muamalah yaitu hubungan antara sesama manusia, hubungan manusia dengan makhluk lain dan dengan alam sekitarnya, seperti sosial budaya, pertanian, tehnologi, tidak terkecuali di bidang ekonomi. Islam memandang penting persoalan ekonomi, hal ini dikarenakan ekonomi merupakan bagian dari kehidupan manusia yang tidak dapat dipisahkan, namun bukanlah merupakan tujuan akhir dari kehidupan ini melainkan sebagai sasaran untuk mencapai tujuan yang lebih baik. Setiap manusia mempunyai kebutuhan pokok yaitu sandang, pangan, dan papan (Pratomo, 2016: 1).

Zakat merupakan Rukun Islam yang ketiga yang wajib dilaksanakan oleh orang yang memiliki sejumlah harta tertentu. Zakat juga merupakan salah satu sendi pokok ajaran Islam. Zakat merupakan ibadah yang berkaitan dengan harta benda. Harta benda yang didapat atas usaha manusia yang mendatangkan hasil dan keuntungan berpengaruh terhadap pertumbuhan dan perkembangan zakat (Syamsudin, 2010: 2).

Pendistribusian zakat mempunyai kekhususan tersendiri, yaitu oleh umat Islam, untuk umat Islam dan dikelola oleh umat Islam dengan sasaran khusus seperti tersebut dalam firman Allah Swt:

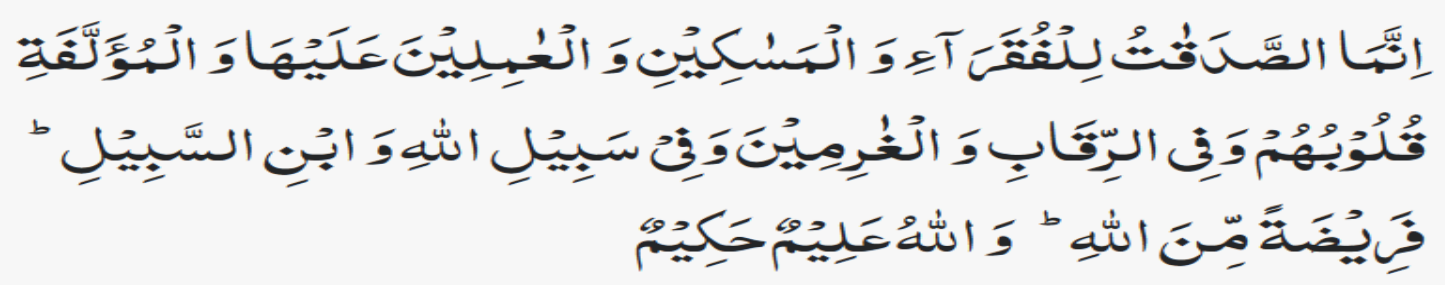

Artinya : "Sesungguhnya zakat-zakat itu, hanyalah untuk orang-orang fakir, orang-orang miskin, pengurus-pengurus zakat, Para mu'allaf yang dibujuk hatinya, untuk (memerdekakan) budak, orang-orang yang berhutang, untuk jalan Allah dan untuk mereka yang sedang dalam perjalanan, sebagai suatu ketetapan yang diwajibkan Allah, dan Allah Maha mengetahui lagi Maha Bijaksana”.(Q.S At-Taubah [9]:60)

Dengan demikian, jumlah dana yang didistribusikan harus berbeda-beda sesuai dengan tempat, waktu, jenis usaha, dan sifat-sifat penerima zakat. Untuk itu memanfaatkan serta mendayagunakan zakat memerlukan kebijaksanaan dan visi kemaslahatan dari pemerintah selaku amil zakat. Zakat produktif bukan istilah jenis zakat seperti halnya zakat mal dan zakat fitrah. Zakat produktif adalah bentuk pendayagunaan zakat. Jadi, pendistribusiannya bersifat produktif yaitu untuk menambah atau sebagai modal usaha mustahik (Magfiroh, 2007: 43).

Oleh karena itu peranan Organisasi Pengelola Zakat (OPZ) berupa BAZNAS dan LAZ sangat diperlukan untuk pendayagunaan zakat agar lebih efektif dan efisien. Keberadaan 
BAZNAS dan LAZ merupakan salah satu ketentuan penting yang terdapat dalam UndangUndangNo.23 Tahun 2011 tentang Pengelolaan Zakat. Keberadaan BAZNAS dan LAZ dimaksudkan untuk memaksimalkan sistem pengelolaan zakat agar berhasil guna dan berdaya guna, sehingga pelaksanaan zakat dapat efektif dan efisien.

Di Indonesia terdapat BAZNAS di tingkat pusat propinsi dan tingkat Kabupaten/Kota, salah satunya adalah BAZNAS Kabupaten Tanah Datar. BAZNAS Kabupaten Tanah Datar merupakan salah satu Organisasi Pengelola Zakat yang dibentuk oleh pemerintah. Sesuai dengan namanya, BAZNAS Kabupaten Tanah Datar merupakan Badan Amil Zakat yang bertugas untuk mengelola dan mendistribusikan zakat di wilayah Kabupaten Tanah Datar. Dana zakat yang dikelola oleh BAZNAS Kabupaten Tanah Datar pada tahun 2016 adalah sebanyak Rp. 11.148.298.358,- dan telah didistribusikan sebesar 9.079.113.287 kepada mustahik yang ada di Kabupaten Tanah Datar dalam beberapa program yaitu: Tanah Datar Cerdas, Tanah Datar Makmur, Tanah Datar Sehat, Tanah Datar Taqwa, dan Tanah Datar Peduli.

\section{Tabel 1.}

Pendistribusian Dana Zakat BAZNAS Kabupaten Tanah Datar Tahun 2016

\begin{tabular}{|c|c|}
\hline Program Distribusi/Penyaluran & Jumlah \\
\hline Tanah Datar Cerdas & 2.947 .035 .000 \\
\hline Tanah Datar Makmur & 2.618 .040 .000 \\
\hline Tanah Datar Sehat & 312.170 .000 \\
\hline Tanah Datar Peduli & 1.810.020.000 \\
\hline Tanah Datar Taqwa & 177.764 .000 \\
\hline $\mathrm{ZCD}$ & 155.000 .000 \\
\hline Amil (Operasional) & 1.059 .084 .287 \\
\hline Total & 9.079.113.287 \\
\hline
\end{tabular}

Sumber :Data diolah, 2017

Dari tabel di atas diperoleh informasi bahwa 28,84\% dari total pendistribusian BAZNAS Kabupaten Tanah Datar dialokasikan pada program Tanah Datar Makmur, program pendistribusian Tanah Datar Makmur adalah program yang digunakan untukmemaksimalkan potensi zakatdalam upaya meningkatkan ekonomi/kesejahteraan masyarakat, yang dilakukan dengan dua cara yaitu pendistribusian zakat secara konsumtif dan produktif. Pendistribusian zakatsecara konsumtif yaitu pendistribusian yang dilakukan dengan tujuan memenuhi kebutuhan dasar ekonomi para mustahik berupa pemberian bahan makanan dan lain-lain serta bersifat pemberian untuk dikonsumsi secara langsung, 
sedangkan pendistribusian zakat secara produktif yaitu pengelolaan zakat dengan tujuan pemberdayaan dan biasa dilakukan dengan cara bantuan modal pengusaha lemah.

Program Tanah Datar Makmur merupakan salah satu program pendistribusian yang menarik untuk dikaji karena didalamnya banyak dibentuk program-program lanjutan untuk memberdayakan masyarakat yang ada di Kabupaten Tanah Datar dengan berbagai usaha produktif, yang diberikan kepada mustahik yang layak menerima bantuan zakat tersebut, dan cara pendistribusian dana zakat oleh BAZNAS Kabupaten Tanah Datar dilakukan dengan 2 tahapan, yaitu tahap I dan tahap II.

Tahap I maksudnya adalah pemberian/pendistribusian dilakukan dari bulan Januari sampai dengan bulan Juni, sedangkan tahap II dilakukan pada bulan Juli sampai dengan bulan Desember. Hal ini berlaku di setiap Kecamatan yang ada di Kabupaten Tanah Datar, salah satunya Kecamatan Lima Kaum, dimana kecamatan Lima Kaum masih banyak keluarga miskin/kurang mampu. Pendistribusian dana zakat produktif di kecamatan Lima Kaum tahun 2016 pada tahap pertama sebanyak 32 orang mustahik, dana yang didistribusikan sebanyak Rp. 76.500.ooo,- dan pendistribusian pada tahap kedua sebanyak 40 orang mustahik, dana yang didistribusikan sebanyak Rp. 131.000.000,-. Berikut keseluruhan mustahik di Kecamatan Lima Kaum pada tahun 2016.

Tabel 2.

Pendistribusian Dana Zakat Produktif Kecamatan Lima Kaum Tahap I dan Tahap II Tahun 2016

\begin{tabular}{|c|c|c|c|}
\hline No. & Jenis Usaha & $\begin{array}{c}\text { Jumlah } \\
\text { mustahik }\end{array}$ & $\begin{array}{c}\text { Dana yang di } \\
\text { distribusikan }\end{array}$ \\
\hline 1. & Berdagang & 46 Orang & 124.500 .000 \\
\hline 2. & Berternak & 20 Orang & 65.000 .000 \\
\hline 3. & Bertani & 5 Orang & 15.000 .000 \\
\hline 4. & Bengkel & 1 Orang & 3.000 .000 \\
\hline \multicolumn{2}{|r}{ Jumlah } & $\mathbf{7 2}$ Orang & Rp. 207.500.000 \\
\hline
\end{tabular}

Sumber: Data diolah 2017

Dari tabel di atas dapat kita pahami bahwa pendistribusian dana untuk usaha berdagang lebih besar yaitu 60\% dari keseluruhan dana yang dialokasikan untuk Kecamatan Lima Kaum. Dengan demikian pendistribusian zakat produktif di Kecamatan Lima Kaum didominasi oleh modal usaha untuk berdagang. Tujuan dari pemberian modal usaha berdagang ini adalah untuk membantu mustahik yang mempunyai keahlian dalam usaha berdagang tetapi kekurangan modal, dengan harapan modal tersebut dapat meningkatkan pendapatan mereka selanjutnya.

Menurut bapak Alfidayat, wawancara, Sabtu, o6 November 2017, dimana beliau adalah pegawai BAZNAS Kabupaten Tanah Datar yang bertugas di UPZ Kecamatan Lima 
Kaum menyatakan bahwa penerima dana zakat/mustahik modal usaha berdagang sebagian besar tidak mengalami perkembangan, hal ini disebabkan oleh perilaku/karakter mustahik itu sendiri, kurang pahamnya mustahik dalam mengelola dalam mengelola dana zakat yang diterima, dan pendistribusian dana zakat di Kecamatan Lima Kaum kurang membantu dalam meningkatkan pendapatan mereka.

Berdasarkan uraian diatas penulis tertarik untuk mengetahui apakah dengan pendistribusian dana zakat produktif yang dikelola oleh BAZNAS Kabupaten Tanah Datar dapat meningkatkan pendapatan mustahik penerima zakat produktif

\section{METODE PENELITIAN}

\section{Jenis Penelitian}

Jenis penelitian yang penulis lakukan adalah penelitian lapangan (field research), yaitu suatu penelitian yang mengungkapkan dan menggambarkan kejadian-kejadian, fenomena dan data yang terjadi di lapangan yang dilakukan disuatu lokasi yang berada di tengah-tengah masyarakat sebagaimana adanya sesuai dengan kenyataan yang ada dimana penelitian yang dilakukan (Tim Penyusun, 2014: 18). Penelitian ini menggunakan metode analisis deskriptif dengan pendekatan kualitatif. Di mana penulis memperoleh data yang dibutuhkan dalam pembahasan penulis dari BAZNAS Kabupaten Tanah Datar, yang terkait tentang perkembangan pendapatan mustahik penerima zakat produktif BAZNAS Kabupaten Tanah Datar.

\section{Latar dan Waktu Penelitian}

Penelitian ini dilakukan pada bulan Agustus 2017 sampai bulan Januari 2018 pada saat jam kerja. Penelitian ini bertempat pada BAZNAS Kabupaten Tanah Datar dan di Kecamatan Lima Kaum.

\section{Instrumen Penelitian}

Dalam penelitian, yang menjadi instrumen penelitian adalah penulis sendiri. Peneliti menggunakan beberapa alat pendukung yaitu pedoman wawancara berupa daftar pertanyaan, guna mendapatkan data dari pihak BAZNAS Kabupaten Tanah Datar dan mustahik Kecamatan Lima Kaum. Instrumen yang menunjang kelengkapan yaitu buku catatan, pena, camera dan tape recorder atau alat perekam.

\section{Sumber Data}

Adapun sumber data yang penulis gunakan dalam penelitian ini adalah sebagai berikut sumber data primer yaitu petugas pendistribusian zakat BAZNAS Kabupaten Tanah Datar serta mustahik zakat produktif BAZNAS Kabupaten Tanah Datar yang mempunyai usaha dagang di Kecamatan Lima Kaum. Dan sumber data sekunder yang berasal dari 
dokumen-dokumen BAZNAS Kabupaten Tanah Datar untuk mendapatkan informasi. Dalam hal ini, yang menjadi sumber data sekunder yaitu dokumen-dokumen yang berkaitan dengan data mustahik.

\section{Teknik pengumpulan data}

Adapun teknik pengumpulan data yang terkait dengan penelitian yang penulis lakukan meliputi observasi yang dilakukan secara langsung di BAZNAS Kabupaten Tanah Datar untuk mengamati pengelolaan zakat, selain itu penulis juga melakukan wawancara dengan menggunakan instrument penelitian berupa pertanyaan-pertanyaan tertulis/pedoman wawancara, selain menggunakan pedoman wawancara penelti juga dapat menggunakan alat bantu seperti tape recorder, gambar, dan lain sebagai sebagai alat pendukung dalam wawancara tersebut (Sugiyono, 2007: 319).

Dari 46 mustahik di Kecamatan Lima Kaum yang memiliki usaha berdagang diwawancarai sebanyak 13 orang mustahik dengan alasan biaya yang tersedia dan tingkat ketelitian yang diperlukan sesuai dengan Metode Sampling Acak Sederhana (MSASederhana), merupakan metode penarikan atau pemilihan contoh yang sederhana dan paling mudah digunakan, metode ini hanya sesuai digunakan terhadap populasi yang anggota-anggotanya mempunyai karakter homogen (Hanafiah, 2010: 65).

Observasi dan wawancara telah dilakukan, maka dikuatkan lagi dengan dukungan dokumentasi, dokumentasi yang digunakan oleh penulis dalam penelitian ini adalah dokumen yang berkaitan dengan distribusi dana zakat, jumlah mustahik, laporan tahunan, surat/SK, brosur, letak geografis, sarana prasarana juga struktur organisasi di BAZNAS Kabupaten Tanah Datar.

\section{Teknik Pengolahan Data}

Setelah data terkumpul, penulis akan mengolah data tersebut dengan melakukan penyeleksian terhadap data, kemudian diklasifikasikan sesuai aspek masalah yang telah disusun. Data yang penulis peroleh kemudian akan diolah dan dianalisis untuk melihat pengaruh pendisrtibusian dana zakat produktif terhadap pendapatan mustahik penerima zakat BAZNAS Kabupaten Tanah Datar. Kemudian, penulis mengolahnya dengan teknik analisis deskriptif dengan pendekatan kualitatif.

\section{Teknik Analisis data}

Teknik analisa data yang digunakan adalah triangulasi. Teknik triangulasi dalam penelitian ini adalah untuk menguji kredibilitas/kepercayaan data kepada sumber yang sama dengan teknik yang berbeda. Pada awalnya penulis memperoleh data melalui observasi lalu dilakukan wawancara dan selanjutnya adalah dengan dokumentasi. Untuk menganalisis 
data yang diperoleh, penulis menggunakan metode deskriptif kualitatif dan deskriptif kuantitatif.

Deskriptif Kualitatif yaitu mengumpulkan, menyusun, mengklasifikasikan data yang diperoleh, kemudian diinterprestasikan sehingga memberikan informasi yang lengkap tentanganalisis pengaruh pendisrtibusian dana zakat produktif terhadap pendapatan mustahik penerima zakat BAZNAS Kabupaten Tanah Datar. Setelah data dikelola secara deskriptif kualitatif kemudian data akan dikelola dengan menggunakan analisis Statistik deskriptif, yaitu memberikan gambaran atau deskripsi suatu data yang dilihat dari nilai rata-rata (mean), maksimum, minimum, range (Djarwanto, 2001: 43). Dalam hal ini penelitian memberikan gambaran pengaruh dana zakat produktif terhadap pendapatan mustahik di Kecamatan Lima Kaum.

Rata-rata (Mean): $\bar{y}=\frac{\sum y i}{n}$

Keterangan:

$$
\begin{aligned}
& \bar{y}=\text { Nilai rata-rata } \\
& n=\text { Jumlah sampel } \\
& y_{i}=\text { Frekuensi masing-masing data }
\end{aligned}
$$

\section{HASIL DAN PEMBAHASAN Program Tanah Datar Makmur}

Tanah Datar Makmur merupakan bantuan modal usaha yang diberikan kepada keluarga miskin untuk melaksanakan usaha secara produktif seperti bertani, berternak, berdagang dan usaha lainnya. Program tanah datar makmur dilaksanakan dengan memberikan bantuan awal kepada mustahik yang baru memulai usahanya atau mustahik yang sudah memiliki usaha dan melanjutkannya (Dokumen BAZNAS Kabupaten Tanah Datar, 2017).

Dalam pemberian bantuan berupa modal untuk usaha produktif ini, pihak BAZNAS memberikan kuota untuk instansi-instansi dalam hal ini adalah muzaki, untuk mengusulkan mustahik yang berhak menerima bantuan tersebut. Kemudian pihak BAZNAS Kabupaten Tanah Datar melakukan survei terhadap mustahik yang diusulkan oleh muzakki, hal ini dilakukan untuk melihat layak atau tidaknya mustahik tersebut menerima bantuan modal usaha ini (Dokumen BAZNAS Kabupaten Tanah Datar, 2017).

Setelah melakukan survei dan mendapatkan mustahik yang layak untuk diberikan bantuan kemudian bidang pendistribusian BAZNAS Kabupaten Tanah Datar memberikan bantuan dana zakat dalam bentuk barang kepda mustahik, jika usaha mustahik itu berdagang maka pihak BAZNAS akan membelikan barang dagangan, jika usaha mustahik itu 
berternak maka hewan ternak yang akan diberikan kepada mustahik tersebut (Dokumen BAZNAS Kabupaten Tanah Datar, 2017).

\section{Pelaksanaan Pendistribusian Dana Zakat Produktif pada BAZNAS Kabupaten Tanah Datar}

Dari semua bidang dalam pendistribusian dana zakat yang ada pada BAZNAS Kabupaten Tanah Datarpenulis ingin mengetahui pelaksanaan pendistribusian dana zakat dalam bidang ekonomi atau yang biasa disebut zakat produktif yang mengacu pada SOP pendistribusian zakat BAZNAS Kabupaten Tanah Datar. Pelaksanaan pendistribusian dana zakat produktif pada BAZNAS Kabupaten Tanah Datar dilakukan dengan beberapa tahapan (Wawancara, Faisal, 2018) yaitu mustahik penerima zakat diusulkan langsung oleh muzaki, pihak BAZNAS melakukan survei untuk melihat keadaan mustahik yang diusulkan oleh muzaki, mustahik dikelompokkan untuk layak menerima dengan yang tidak layak, setelah mengetahui mustahik yang layak untuk menerima zakat, maka pihak BAZNAS melakukan servei kedua untuk melihat persiapan usaha mustahik, dan pemberian dana zakat kepada mustahik.

Dana zakat yang akan didistribusikan kepada mustahik di berikan berikan kepada UPZ Kecamatan yang ada di Kabupaten Tanah Datar setelah dana diterima oleh UPZ maka akan diberikan kepada mustahik, pemberian bantuan dana zakat kepada mustahik bukan semata-mata hanya memberikan uang, akan tetapi pihak UPZ menemani dan mengontrol dalam membelanjakan dana untuk kepentingan dan kebutuhan usaha yang akan dijalankan oleh mustahik tersebut. Penggunaan uang yang diberikan oleh BAZNAS Kabupaten Tanah Datar ini harus sesuai dengan perencanaan usaha. Besar dana yang akan diberikan kepada mustahik disesuaikan dengan kebutuhan usaha mustahik itu sendiri.

BAZNAS Kabupaten Tanah Datarmemberikan batasan dalam jumlah bantuan yang akan disalurkan kepada mustahik ketentuannya sebagai berikut:

a. Dalam bidang usaha berdagang maksimal dana yang diberikan sebesar Rp. 3.0oo.ooo,-, namun kembali lagi kepada jenis usaha yang dijalankan mustahik tersebut, misalnya mustahik hanya akan menjual gorengan, maka modal yang akan diberikan itu kurang dari Rp. 3.000.000,- namun dalam kasus lain yang pernah terjadi, seorang mustahik yang memiliki usaha jualan gorengan hanya mengguanakn meja saja, maka BAZNAS Kabupaten Tanah Datar membuatkan warung kecil untuk usaha jualannya dan sisa uang akan diberikan sebagai modal dagangnya.

b. Usaha ternak kambing maksimal dana yang diberikan adalah sebesar Rp. 7.000.0oo,-

c. Usaha ternak ayam atau itik maksimal dana yang diberikan adalah sebesar Rp. 4.000.000,-

d. Usaha pertanian makasimal dana yang diberikan adalah sebesar Rp. 4.000.00o,- 
Upaya yang dilakukan oleh BAZNAS Kabupaten Tanah Dataragar dana yang didistribusikan digunakan secara efektif oleh mustahik, dengan cara melakukan monitoring terhadap usaha yang dijalankan mustahik penerima zakat, dalam peraturanyang lama monitoring dilakukan hanya enam bulan sekali, namun sekarang monitoring satu bulan sekali. Jika usaha dagang yang dijalankan baik dan kemauan usaha mustahik itu tampak jelas maka modal akan ditambah. Namun jika tidak berkembang maka modal tidak akan diberikan lagi. Tujuan hal tersebut adalah agar mustahik keluar dari kemiskinan.

Apabila dari hasil monitoring mendapatkan bahwa ada salah satu mustahik yang mengalami kesulitan dalam usahanya dan kemudian usaha tersebut tidak berkembang, maka tidak ada hukuman pengembalian dana yang telah diberikan, sebab BAZNAS Kabupaten Tanah Datarhanya membantu mustahik dalam hal permodalan usaha saja, jika mustahik tidak mampu mengembangkan usahanya maka mereka sendiri yang akan rugi (wawancara, Alfidayat, 2018).

Permasalah yang sering dihadapi oleh BAZNAS Kabupaten Tanah Dataruntuk pendistribusian dana zakat produktif berasaldari dari mustahik itu sendiri, seperti manajemen kewirausahaan mustahik, mustahik tidak mau menabung saat disarankan kemudian yang menjadi kendala dalam pendistribusian adalah mental mustahik tersebut, seperti tidak bersungguh-sungguhnya mustahik tersebut dalam menjalankan usahanya (wawancara, Faisal, 2018), sebagian besar mustahik tidak menyadari bahwa ini adalah bantuan zakat yang sangat jauh berbeda dengan dana bantuan dari pemerintah, pemikran mustahik yang menganggap bahwa zakat ini akan selalu diberikan secara terus menerus, kebutuhan yang sangat tinggi sedangkan usaha tambahan tidak ada, pemenuhan kebutuhan kebutuhan sehari-hari hanya bergantung pada usaha yang dibantu oleh BAZNAS Kabupaten Tanah Datarsaja (Alfidayat, 2018).

\section{Perkembangan Pendapatan Mustahik Sebelum dan Sesudah Menerima Bantuan Zakat dari BAZNAS Kabupaten Tanah Datar}

Roma Deni bertempat tinggal di Jorong Dusun Tuo Kecamatan Lima Kaum. Roma Deni mempunyai usaha gorengan kecil-kecilan. Tempat jualannya hanya dengan meja seadanya di depan rumahnya. Sebelum mendapat modal dari BAZNAS Kabupaten Tanah Datar, modal awal Roma Deni lebih kurang Rp.1.ooo.ooo,- dengan modal yang dimiliki tersebut Roma Deni mempunyai pendapatan sebesar Rp. 1.200.000,-. Pendapatan yang diperoleh dari jualan gorengan tersebut tergolong kecil, karena hasil penjualan satu hari habis dalam satu hari. Kemudian memperoleh bantuan dari BAZNAS Kabupaten Tanah Datar sebesar Rp. 3.000.000,- sehingga pendapatan Roma Deni bertambah menjadi Rp. 1.800.000,-/bulan, Roma Deni mengakui dengan adanya bantuan zakat dari BAZNAS Kabupaten Tanah Datar ini, pendapatan yang diperoleh lebih banyak dari pada pendapatan sebelum diberi zakat, sehingga dapat memenuhi kebutuhan sehari-hari. Usaha Roma Deni tersebut masih berjalan sampai sekarang (wawancara, Roma Deni, 04 Januari 2018). 
Zul Emri berdomisili di Nagari Cubadak Kecamatan Lima Kaum, Beliau memiliki usaha julan nasi ampera setiap hari Kamis di sebelah pasar ternak Cubadak dan untuk hari lain Zul Emri jualan barang harian. Modal awal untuk membuka usaha tersebut adalah sebesar Rp.6.000.000,- dengan pendapatan perbulannya sebesar Rp. 1.800.000,-. Dengan penghasilan yang diperolehnya tersebut hanya mencukupi untuk kebutuhan hidup saja, hal ini disebabkan oleh Zul Emri masih memiliki hutang. Di samping itu ia juga harus memenuhi biaya pendidikan anak-anaknya. Jadi dengan penghasilan usaha jualan Zul Emri ini tidak memenuhi semua kebutuhan keluarga. Kemudian Zul Emri memperoleh bantuan zakat untuk usaha sebesar Rp. 3.000.000,- sehingga pendapatan Zul Emri meningkat yaitu Rp. 2.400.000,- atau 33\% dari pendapatan sebelumnya. Usaha Zul Emri masih berjalan sampai sekarang. Dengan adanya bantuan dari BAZNAS Kabupaten Tanah Datar ini sangat membantu kehidupan keluarga Zul Emri. Hutang berkurang dan semua kebutuhan dapat terpenuhi dengan baik (wawancara, Zul Emri, 04 Januari 2018)

Mairizal bertempat tinggal di Jorong Jati Nagari Baringin Kecamatan Lima Kaum, Beliau adalah mustahik zakat dengan usaha jualan ikan kering. Dengan penghasilan yang diperoleh tidak dapat memenuhi kebutuhan hidup sehari-hari, dalam setiap harinya penghasilan Mairizal hanya Rp.100.00o sedangkan kebutuhan setiap harinya adalah Rp. 125.00o. Kondisi ini dikarenakan biaya kuliah 2 orang anaknya ditambah dengan kebutuhan rumah tangga. Makanya dengan modal awal sebesar Rp. 2.000.000,- dan pendapatan perbulannya sebesar Rp. 3.000.000,-, dengan pendapatan tersebut Mairizal tidak mampu memenuhi kebutuhan sehari-harinya. Kemudian Mairizal memperoleh bantuan zakat sebesar Rp. 3.000.000,- sehingga pendapatan Mairizal bertambah menjadi Rp. 3.750.000,-, atau 25\% dari pendapatan sebelumnya, dengan pendapatan tersebut Mairizal mampu memenuhi kebutuhan sehari-hari keluarganya sampai sekarang dengan usaha yang sama (wawancara, Mairizal, o6 Januari 2018).

Chandra Chairani bermukim di Jorong Parak Juar Nagari Baringin Kecamatan Lima Kaum. Ia adalah mustahik zakat yang berprofesi sebagai buruh cuci di sekitar tempat tinggalnya. Penghasilannya sebagai buruh cuci tergolong sangat kecil yaitu sebesar Rp. 1.200.000,- perbulan. Penghasilannya tersebut yang belum dapat memenuhi kebutuhan rumah tangganya dan biaya pendidikan anaknya, karena penghasilan keluarga hanya mengandalkan dari gaji yang diperoleh oleh Chandra Chairani sebagai buruh cuci. Ibu Chandra Chairani memperoleh bantuan dari BAZNAS Kabupaten Tanah Datar sebesar Rp. 4.000.00o,- yang digunakan oleh Chandra Chairani untuk usaha rumahan membuat kue kering, dengan bantuan tersebut pendapatan meningkat menjadi Rp. 2.250.000,-/bulannya, atau $87 \%$ dari pendapatan sebelumnya usaha Chandra Chairani masih berjalan sampai sekarang. Dengan bantuan yang diperoleh dari BAZNAS Kabupaten Tanah Datar ini, kebutuhan Chandra Chairani dapat terpenuhi dengan baik (wawancara, Chandra Chairani, o6 Januari 2018).

Endang Sri Mulyati adalah mustahik zakat berusia 60 tahun yang bertempat tinggal di nagari Baringin Kecamatan Lima Kaum. Ia tinggal bersama seorang cucunya. Awalnya Endang Sri Mulyati ini bekerja sebagai buruh cuci di sekitar tempat tinggalnya. Sebelum menerima bantuan zakat Endang bekerja sebagai buruh cuci di kawasan tempat tinggalnya, dengan pendapatan perbulannya sebesar Rp. 1.050.000,-. Penghasilan tersebut digunakan untuk memenuhi kebutuhan hidup sehari-hari dan biaya sekolah cucunya. Dengan besarnya biaya hidup sehari-hari dan biaya sekolah cucunya, hasil yang diperoleh oleh Endang ini tidak mencukupi kebutuhan hidupnya. Kemudian Endang memperoleh bantuan zakat dari BAZNAS Kabupaten Tanah Datar sebesar Rp. 2.500.000,- yang digunakan Endang untuk berjualan gorengan harian di sekitar tempat tinggalnya, sehingga pendapatan Endang menjadi sebesar Rp. 1.80o.ooo,-, akan tetapi usaha Endang tidak berjalan lagi sejak Endang mengalami sakit sekitar 6 bulan yang lalu. Modal yang dimiliki habis karena biaya berobat. 
Sehingga saat ini Endang kembali bekerja sebagai buruh cuci (wawancara, Endang Sri Mulyati, o6 Januari 2018).

Tina Marlina adalah mustahik zakat yang bertempat tinggal di Lantai Batu Kecamatan Lima Kaum yang memiliki usaha rumahan dengan modal Rp. 1.000.000,-, dengan pendapatan lebih kurang sebesar Rp. 1.00o.ooo,-/bulannya, kemudian Tina mendapat bantuan BAZNAS Kabupaten Tanah Datar sebesar Rp. 3.000.00o,- sehingga pendapatan ibu Tina meningkat menjadi Rp. 1.800.000,-/bulan, atau 80\% dari pendapatan sebelumnya, usaha Tina Masih berjalan sekarang (wawancara, Tina Marlina, o6 Januari 2018).

Angga berdomisili di Nagari Baringin Kecamatan Lima Kaum. Beliau bekerja sebagai satpam di sebuah sekolah di Nagari Baringin. Istrinya bekerja sebagai pedagang di sekolah tersebut dengan fasilitas seadanya yaitu hanya dengan meja saja. Modal awal istri Angga berjualan adalah sebesar Rp.3.000.000,-, dengan pendapatan sebesar Rp. 1.500.000,/bulan, kemudian Angga dan istrinya memperoleh bantuan zakat dari BAZNAS Kabupaten Tanah Datar Rp. 1.500.000,-. Dana tersebut digunakan untuk membuat tempat berjualan yang layak sehinga pendapatan dari hasil usaha jualan tersebut menjadi sebesar Rp. 2.400.000,-/bulan atau sebesar 60\% dari pendapatan sebelumnya. Usaha jualan Angga dan istrinya masih berjalan sampai sekarang (wawancara, Angga Ferdian, o6 Januari 2018).

Yessy bertempat tinggal di Jorong Lantai Batu Nagari Baringin Kecamatan Lima Kaum. Ia merupakan mustahik dengan profesi sebagai penjual ban bekas. Modal awal yang dimiliki dalam usaha berjualan ban bekas adalah sebesar Rp. 1.000.00o,- dengan pendapatan per bulannya sebesar Rp. 2.400.000,-, kemudiaan Yessy memperoleh bantuan usaha zakat sebesar Rp. 3.00o.ooo,- yang dipergunakan untuk membeli kompresor guna untuk menunjang usaha Yessy, sehingga pendapatan Yessy sekarang menjadi Rp. Rp.4.500.000,-/bulan atau 88\% dari pendapatan sebelumnya. Dengan besarnya pendapatan Yessy dari penjualan ban bekas ini, usaha Yessy ini sampai sekarang masih berjalan dan hingga saat ini Yessy dapat mengembangkan usahanya dengan membuka sebuah bengkel motor (wawancara, Yessy Aprilia Sari, o6 Januari 2018).

Nasri merupakan seorang petani yang berdomisili di Baringin Kecamatan Lima Kaum. Pendapatan Nasri sebagai petani per bulannya sebesar Rp. 1.500.000,- merupakan upah yang didapat Nasri dari hasil membajak sawah. Dengan pendapatan yang minim ini, Nasri tidak dapat memenuhi kebutuhan sehari-hari, ditambah lagi Nasri mempunyai 2 orang anak yang masih berada di bangku pendidikan. Setelah di survey oleh pihak BAZNAS Kabupaten Tanah Datar Nasri memperoleh bantuan sebesar Rp. 2.000.0oo,- untuk membuka usaha jualan makanan di depan rumahnya, sehingga pendapatan Nasri bertambah menjadi Rp. 2.100.000,-/bulan atau meningkat 40\% dari pendapatan sebelumnya. Akan tetapi, usaha jualan makanan tersebut hanya bertahan 8 bulan saja. Hal ini dikarenakan Nasri dalam keadaan sakit dan tidak bisa di wawancarai, maka pewawancara mewawancarai Silvia, anak dari Nasri (wawacara, Nasri, o6 Januari 2018).

Dalrius Telmi bertempat tinggal di Jorong Pilang Kecamatan Lima Kaum, usaha yang dimiliki adalah jualan nasi ampera dengan modal awal sebesar Rp. 3.000.000,- pendapatan per bulan Dalrius Telmi adalah sebesar Rp. 1.800.000,- kemudian Dalrius memperoleh bantuan BAZNAS Kabupaten Tanah Datar sebesar Rp. 3.000.00o,- dengan bantuan BAZNAS Kabupaten Tanah Datar tersebut Dalrius Telmi mengaku mengalami kerugian, sebab bantuan tersebut tidak digunakan untuk kegiatan usahanya akan tetapi digunakan untuk membeli kulkas (wawancara, Dalrius Telmi, o7 Januari 2018).

Gusnimar adalah seorang penjual kue kering yang biasanya berjualan di Jorong Koto Gadih. Dalam menjual kue kering ini Gusnimar harus berhutang ke warung dekat rumahnya sebesar Rp. 3.600.000,- sebagai modal awal dalam berjualan kue kering. Dengan berjualan 
kue kering ini Gusnimar memperoleh pendapatan sebesar Rp. 600.000,-/bulan. Pendapatan dari hasil usaha kue kering ini tidak mampu memenuhi kebutuhan sehari-hari. Kemudian Gusnimar memperoleh bantuan BAZNAS Kabupaten Tanah Datar sebesar Rp. 4.000.000,- yang digunakan untuk modal usaha jualan kue kering, dengan bantuan dari BAZNAS Kabupaten Tanah Datar ini pendapatan Gusnimar menjadi Rp. 1.200.000,-, atau sebesar 100\% dari pendapatan sebelumnya (wawancara, Gusnimar, 05 Januari 2018).

Andri adalah seorang mustahik zakat yang bekerja sebagai seorang tukang. Andri bersama keluarganya tinggal di Nagari Baringin Kecamatan Lima Kaum. Awalnya usaha istri Andri ini adalah di rumah dengan modal awal Rp. 2.500.000,- dengan pendapatan perbulannya sebesar Rp. 1.800.000,-. Modal yang sedikit membuat barang yang dijual oleh istri Andri juga tidak terlalu banyak dan pendapatan pun tidak begitu banyak. Dengan kebutuhan yang besar dan penghasilan yang tidak banyak, kemudian Andri memperoleh bantuan dari BAZNAS Kabupaten Tanah Datar sebesar Rp. 3.00o.ooo,- sehingga pendapatan dari hasil usaha tersebut menjadi Rp. 3.000.00o,-/bulan, dan usaha istri Andri tersebut masih berjalan sampai sekarang. Usaha yang dijalankan oleh istri Andri sekarang sudah berkembang dan barang jualannya sudah banyak. Dengan itu maka penghasilan perbulan keluarga Andri meningkat sebesar 67\% dari sebelumnya (wawancara, Andri, o6 Januari 2018).

Warnis adalah mustahik zakat yang bertempat tinggal di Lantai Batu Kecamatan Lima Kaum berusia 65 tahun. Warnis ini tinggal dengan seorang anaknya yang masih duduk di bangku SMA dan seorang cucunya yang masih kecil. Usaha yang dijalankan oleh Warnis ini adalah jualan sayur ke pasar-pasar. Penghasilan yang diperoleh oleh Warnis adalah sebesar Rp. 1.500.000, dengan modal awal sebesar Rp. 1.000.000,-. Dengan penghasilan yang diperoleh tersebut, kebutuhan keluarga Warnis tidak dapat terpenuhi. Kemudian Warnis memperoleh bantuan dari BAZNAS sebesar Rp. 3.000.000,- sehingga pendapatan Warnis menjadi sebesar Rp. 2.100.000,-/bulan atau meningkat sekitar 40\%, dan usaha Warnis masih berjalan sampai sekarang (wawancara, Warnis, o7 Januari 2018).

Dari hasil wawancara yang dilakukan dengan beberapa orang mustahik yaitu sebanyak 13 orang yang ada di Kecamatan Lima Kaum, diperoleh informasi tentang perkembangan pendapatan mustahik, di mana setelah diberikan bantuan zakat sebanyak 12 orang mustahik mengalami peningkatan pendapatan dan satu orang mengaku bahwa usahanya rugi setelah diberi bantuan zakat, dari semua mustahik yang diwawancarai 10 orang yang usaha masih berjalan sampai sekarang.

Tabel 3

Pendapatan Mustahik Kecamatan Lima Kaum

\begin{tabular}{|c|c|c|c|c|c|c|c|}
\hline No. & $\begin{array}{l}\text { Nama } \\
\text { Mustahik }\end{array}$ & Modal Awal & $\begin{array}{l}\text { Pendapatan } \\
\text { Sebelum }\end{array}$ & $\begin{array}{l}\text { Bantuan } \\
\text { Zakat }\end{array}$ & $\begin{array}{l}\text { Pendapatan } \\
\text { Sesudah }\end{array}$ & $\begin{array}{l}\text { Kenaikan } \\
\text { Pendapatan }\end{array}$ & $\begin{array}{l}\text { Persentase } \\
\text { Kenaikan } \\
\text { Pendapatan }\end{array}$ \\
\hline 1. & Roma Deni & 1.000 .000 & 1.200 .000 & 3.000 .000 & 1.800 .000 & 600.000 & $50 \%$ \\
\hline 2. & Zul Emri & 6.000 .000 & 1.800 .000 & 3.000 .000 & 2.400 .000 & 600.000 & $33 \%$ \\
\hline 3. & Gusnimar & 3.600 .000 & 600.000 & 3.000 .000 & 1.200 .000 & 600.000 & $100 \%$ \\
\hline 4. & $\begin{array}{l}\text { Yessy Aprilia } \\
\text { Sari }\end{array}$ & 1.000 .000 & 2.400 .000 & 3.000 .000 & 4.500 .000 & 2.100 .000 & $\mathbf{8 8 \%}$ \\
\hline 5. & Mairizal & 2.000 .000 & 3.000 .000 & 3.000 .000 & 3.750 .000 & 750.000 & $25 \%$ \\
\hline 6. & $\begin{array}{l}\text { Chandra } \\
\text { Chairani }\end{array}$ &.- & 1.200 .000 & 4.000 .000 & 2.250 .000 & 1.050 .000 & $87 \%$ \\
\hline 7. & $\begin{array}{l}\text { Endang Sri } \\
\text { Mulyati }\end{array}$ & - & 1.050 .000 & 2.500 .000 & 1.800 .000 & 750.000 & $71 \%$ \\
\hline 8. & Nasri & - & 1.500 .000 & 2.000 .000 & 2.100 .000 & 600.000 & $40 \%$ \\
\hline
\end{tabular}




\begin{tabular}{|c|c|c|c|c|c|c|c|}
\hline 9. & Tina Marlina & 1.000 .000 & 1.000 .000 & 3.000 .000 & 1.800 .000 & 800.000 & $80 \%$ \\
\hline 10. & $\begin{array}{l}\text { Angga } \\
\text { Ferdian }\end{array}$ & 3.000 .000 & 1.500 .000 & 1.500 .000 & 2.400 .000 & 900.000 & $60 \%$ \\
\hline 11. & Andri & 2.500 .000 & 1.800 .000 & 3.000 .000 & 3.000 .000 & 1.200 .000 & $67 \%$ \\
\hline 12. & Warnis & 1.000 .000 & 1.500 .000 & 3.000 .000 & 2.100 .000 & 600.000 & $40 \%$ \\
\hline 13. & $\begin{array}{l}\text { Dalrius } \\
\text { Telmi }\end{array}$ & 3.000 .000 & 1.800 .000 & 3.000 .000 & - & - & - \\
\hline
\end{tabular}

Sumber: Data dilolah, 2018

\section{Rata-rata kenaikan pendapatan mustahik}

$$
\begin{aligned}
\bar{y} & =\frac{\sum y i}{n} \\
\bar{y} & =\frac{10.550 .000}{13}=811.538 \\
\bar{y} & =\frac{741 \%}{13}=57 \%
\end{aligned}
$$

Dari rumus rumus rata-rata di atas bahwa dengan jumlah sampel sebanyak 13 orang mustahik di Kecamatan Lima Kaum yang diberikan bantuan zakat memiliki rata-rata peningkatan pendapatan sebesar Rp. 811.538.- atau 57\% dari pendapatan sebelum menerima zakat. Nilai maksimum dari peningkatan pendapatan ini adalah sebesar $\mathrm{Rp}$. 2.100.000,-/88\% dari pendapatan sebelum menerima zakat yang diperoleh 1 orang dengan nama Yessy Aprilia Sari. Sementara nilai maksimun dari sisi persentase kenaikan pendapatan adalah $100 \%$, diperoleh oleh mustahik Gusnimar, dimana pendapatan sebelum diberi dana zakat adalah Rp. 600.00o,- sedangkan pendapatan setelah diberi dana zakat adalah Rp. 1.200.000,-. Nilai minimum perkembangan pendapatan usaha mustahik adalah o\%, yang berarti tidak mengalami peningkatan, kondisi ini dialami 1 orang dengan nama Dalrius Telmi.

Berdasarkan pemaparan di atas dapat dicermati pada gambar berikut:

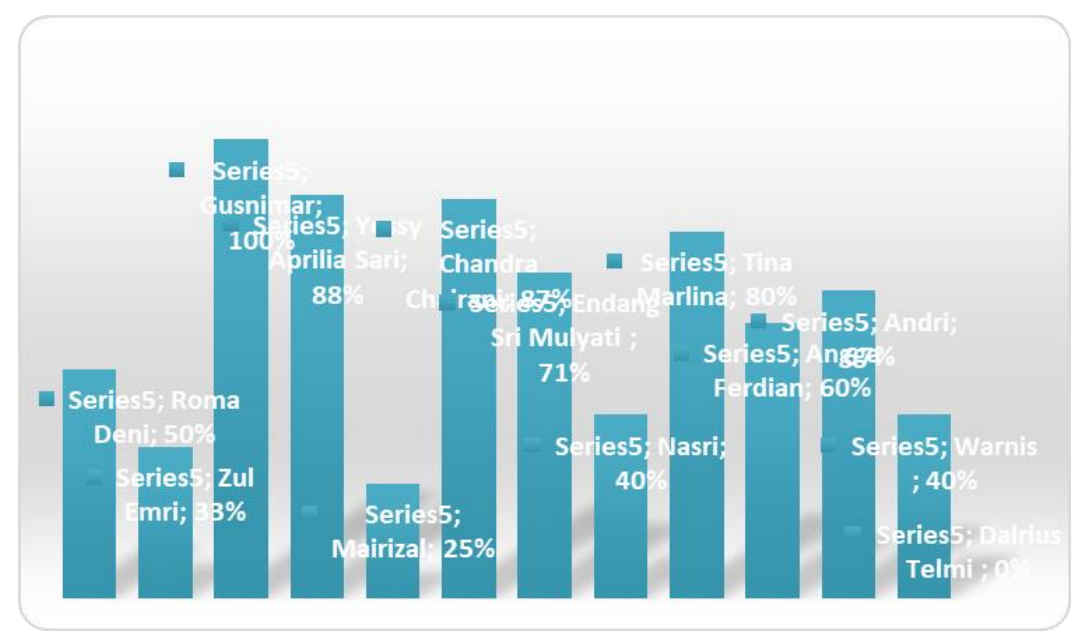

Gambar 1. Persentase Kenaikan Pendapatan Mustahik 
Adanya perbedaan kenaikan pendapatan yang dialami oleh mustahik penerima zakat disebabkan oleh mustahik itu sendiri, pendistribusian dana zakat oleh BAZNAS Kabupaten Tanah Datarsudah tepat sasaran. Akan tetapi pendistribusian dana zakat setelah sampai kepada mustahik banyak terjadi kesalahan atau kendala terhadap pengelolaan dana tersebut, sebab permasalahan dalam pendistribusian dana zakat ini timbul setelah dana itu didistribusiakan, karena banyak dari mustahik setelah menerima bantuan dana zakat tidak menyisihkan sebagian dari pendapatannya untuk ditabung, juga karena kebutuhan hidup yang tinggi. Maka banyak dari mustahik yang usahanya berdagang tidak berusaha lagi sekarang karna kehabisan modal, seharusnya dengan bantuan yang diberikan BAZNAS Kabupaten Tanah Datar dikelola dengan baik dan benar maka mustahik yang dibantu akan mengalami perkembangan ekonominya.

Bukan hanya berkembang untuk memenuhi kebutuhan sehari-hari saja, akan tetapi juga bisa membuka usaha yang lain. Seperti yang dilakukan oleh keluarga ibu Yessy Aprilia Sari sekarang beliau sudah membuka usaha baru dengan hasil yaitu usaha bengkel, modal dari usaha tersebut berasal dari BAZNAS Kabupaten Tanah Datar, pengelolaan usaha yang baik membuat usahanya berkembang. Di samping itu ibu Gusnimar juga berhasil mengelola usahanya dengan baik, kendati belum bisa menyamai pendapatan ibu Yessi Aprillia Sari, namun ibu Gusnimar termasuk mustahik yang berhasil meningkatkan pendapatannya hingga $100 \%$. Dengan demikian diperoleh gambaran bahwa pendistribusian dana zakat yang dilakukan oleh BAZNAS Kabupaten Tanah Datar rata-rata telah meningkatnya pendapatan mustahik, besar kecilnya pendapatan tersebut tergantung pengelolaan usaha oleh mustahik.

\section{KESIMPULAN}

Berdasarkan hasil penelitian yang telah dilakukan diperoleh kesimpulan bahwa pendistribusian dana zakat yang dilakukan oleh BAZNAS Kabupaten Tanah Datar rata-rata telah meningkatnya pendapatan mustahik, besar kecilnya pendapatan tersebut tergantung pengelolaan usaha oleh mustahik itu sendiri. Sebelum pendistribusian dana zakat oleh BAZNAS Kabupaten Tanah Datar pendapatan mustahik tidak dapat mencukupi kebutuhannya sehari-hari, namun setelah menerima bantuan zakat pendapatan mustahik meningkat rata-rata sebesar $57 \%$ dari pendapatan sebelum menerima zakat.

Berdasarkan kesimpulan di atas, disarankan agar BAZNAS Kabupaten Tanah Datar lebih meningkatkan lagi pengelolaan dana zakat produktif, dan pendistribusiannya diberikan kepada orang-orang yang benar-benar layak menerima zakat produktif tersebut, kemudian BAZNAS Kabupaten Tanah Datar harus lebih berkerja keras lagi untuk memberikan bimbingan atau arahan kepada mustahik dalam mengelola usaha yang 
dijalankan khususnya bagi mustahik yang kegiatan usahanya adalah berdagang. Peneliti selanjutnya dapat meneliti aspek-aspek lain yang belum tercakup pada penelitian ini.

\section{DAFTAR PUSTAKA}

Djarwanto. (2001). Mengenal Beberapa Uji Statistik dalam Penelitian. Yogyakarta: LIBERTY YOGYAKARTA

Hanafiah, K, A. Dasar-dasar Statistika. Jakarta: PT Raja Grafindo Persada

Maghfiroh, M. (2007). Zakat.Yogyakarta.: Pustaka Insan Madani.

Pratomo, F. (2016). Efektifitas Pendayaangunaan Zakat Produktif pada Pemberdayaan Ekonomi Mustahiq. Purwokerto: IAIN Purwokerto

Sugiyono. (2007). Metode Penelitian Pendidikan Pendekatan Kuantitatif, Kualitatif, dan $R$ $\& D$. Bandung: Alfabeta

Syamsuddin, S. (2010). Pemberdayaan Ekonomi Umat melalui Zakat Produktif. Jakarta: UIN Syarif Hidayatullah.

Tim Penyusun. (2014). Buku Pedoman Penulisan Skripsi STAIN Batusangkar.Batusangkar: STAIN Batusangkar Press.

Daftar Wawancara

Wawancara, Faisal, Rabu, 10.00 WIB, tanggal o3 Januari 2018, Unit Pendistribusian dan Pendayagunaan.

Wawancara, Alfidayat, Senin, 13.00 WIB, tanggal tanggal o8 Januari 2018 Unit Kecamatan Lima Kaum.

Wawancara,Andri, Sabtu, 17.00 WIB, tanggal o6 Januari 2018 Mustahik Zakat Kecamatan Lima Kaum.

Wawancara, Angga Ferdian, Sabtu, 16.00 WIB, tanggal o6 Januari, Mustahik Zakat Kecamatan Lima Kaum.

Wawancara,Chandra Chairani, Sabtu, 11.0o WIB, tanggal o6 Januari 2018 Mustahik Zakat Kecamatan Lima Kaum.

Wawancara,Dalrius Telmi, Minggu, 10.0o WIB, tanggal o7 Januari 2018 Mustahik Zakat Kecamatan Lima Kaum.

Wawancara, Endang Sri Mulyati, Sabtu, 13.0o WIB, tanggal o6 Januari 2018, Mustahik Zakat Kecamatan Lima Kaum.

Wawancara, Gusnimar, Jumat, 16.00 WIB, tanggal o5 Januari 2018,Mustahik Zakat Kecamatan Lima Kaum.

Wawancara, Mairizal, Sabtu, 09.30 WIB, tanggal o6 Januari 2018,Mustahik Zakat Kecamatan Lima Kaum. 
Wawancara, Nasri, Sabtu, 15.0o WIB,tanggal o6 Januari 2018 Mustahik Zakat Kecamatan Lima Kaum.

Wawancara, Roma Deni, Kamis, 14.0o WIB, tanggal o4 Januari 2018, Mustahik Zakat Kecamatan Lima Kaum.

Wawancara,Tina Marlina, Sabtu, 10.00 WIB, tanggal o6 Januari 2018, Mustahik Zakat Kecamatan Lima Kaum.

Wawancara,Warnis, Minggu, 09.00, tanggal o7 Januari 2018, Mustahik Zakat Kecamatan Lima Kaum.

Wawancara,Zul Emri, Kamis, 15.00 WIB, tanggal o4 Januari 2018, Mustahik Zakat Kecamatan Lima Kaum.

Winoto, G. N. (2011). Pengaruh Dana Zakat Produktif terhadap Keuntungan Usaha Mustahik Penerima Zakat Studi Kasus BAZ Kota Semarang. Skripsi, Fakultas Ekonomi Universitas Diponegoro.

Zuhayly, W. (2005). Zakat Kajian Berbagai Madzhab Bandung. PT. Remaja Rosda Karya. 